\title{
Social Networking Sites Use and Cross Cultural Adaptation of Muslim Indonesian Students in Australian Universities: Valuing Cultural Diversity
}

\author{
Imam Nuraryo \\ Lecturer in Department of Communication, Kwik Kian Gie School of Business Jakarta
}

\begin{abstract}
Muslim Asian students have diverse specific needs when undertaking education in western country universities. Many international students use social networking sites as media for distance communication and helping in their adjustment.

This study attempts to investigate the impact of using new social networking sites on thecross cultural adaptation process.Qualitative methodology was used for the study. Individual in-depth interviews were conducted for data collection. The study investigates social networking uses and the adaptation experiences of 10 Muslim-Indonesian studying (or graduated) in some Australian universities.

This research shows that most Muslim Indonesian students use them just to take information about Islam and instead of using them to publicize Islamic teaching(Dawah). Social networking sites can help for establishing and maintaining relationship their friends in Indonesia, making adjustment, and sharing cultural experiences such as dealing with stereotype or looking for halal food and place for praying. Social networking sites are mostly used to share information and to discuss information about Islam and the way of Muslim adjusting in non Muslim environment.
\end{abstract}

Keywords: Muslim Indonesian Students, Social Networking Sites, Cross Cultural Adaptation

\begin{abstract}
Abstrak
Mahasiswa Muslim yang berasal dari Asia biasanya memiliki kebutuhan khusus yang beragam ketika melanjutkan studi di perguruan tinggi di negara Barat. Banyak mahasiswa tersebut menggunakan situs jejaring sosial sebagai media komunikasi jarak jauh dan membantu dalam penyesuaian diri mereka.

Penelitian ini mencoba untuk menganalisis dampak penggunaan situs jejaring sosial baru pada proses adaptasi lintas budaya. Metode yang digunakan dalam penelitian ini adalah metode kualitatif. Teknik pengumpulan data dalam penelitian ini adalah menggunakan wawancara mendalam pada 10 Muslim Indonesia yang sebagian sedang menjalani perkuliahan dan sebagian lagi baru menyelesaikan studi di beberapa perguruan tinggi di Australia.

Penelitian ini menunjukkan bahwa sebagian besar informan menggunakannya justru untuk mencari informasi tentang Islam dan bukan untuk menggunakan untuk dakwah Islam. Situs jejaring sosial membantu untuk memelihara hubungan pertemanan di Indonesia,membantu penyesuaian diri dan berbagi pengalaman kultural seperti menghadapi stereotipe atau mencari makanan halal dan tempat sholat. Situs jejaring sosial digunakan untuk berbagi informasi tentang Islam dan cara menyesuaikan Muslim di lingkungan non Muslim.
\end{abstract}

Kata kunci:Mahasiswa Muslim Indonesia, Situs Jejaring Sosial, Adaptasi Lintas Budaya 


\section{Introduction}

The Internet is established as one of the most important global communication tool. People across the globe can interact with each other within seconds of sending and receiving messages. The compression of time and space, due to the convergence of new media and globalization, has shrunk the world into a much smaller interactive field, (Chen and Zhang,2010).

Internet through social networking sites has brought people from different cultures together in the "global village." During cross cultural adaptation, people use this media to learn about their host countries, establish and maintain relationships, and stay informed with events in their home countries. Communication and interaction are key factors that influence how social media or social networking sites impacts cross cultural adaptation.

Social networking is an important part of our lives because it promotes the interconnectedness and interdependence of our culturally diverse world. Media for social interaction allows for people to communicate and engage with information that is quickly accessible on the Internet. In today's society, there is an increasing number of Internet users so social networking sites have become more popular in daily patterns and routines. The communication that occurs in these online contexts promotes interactive dialogues that build understanding of different points of view.

In social networking, people have the opportunity to express their opinions to the public and participate in conversations and dialogue through a common virtual medium. People use social networking sites for some reasons. First, the need for connection and interaction with other people is evident.
Social networking provide this opportunity where people can communicate with others and belong to different networks via virtual communities on the net. Second, people use social networking to gain knowledge and learn about different opinions and perspectives of issues, topics, and events. Third, social networking is a form of media that allows people to participate in conversations and online dialogue without being face-to-face with others (Sawyer, 2011:3).

The phrase 'international students' includes a range of different categories: there are those who take a whole degree course (both undergraduate and postgraduate) in a country different from their own, and those who spend only part of their studies abroad, following courses that will contribute to a degree from the home institution. Some students study abroad independently, others have the whole programmed organized by their home university. International students meet specific challenges hence they deserve special concern and attention.

In addition to adjusting to a new education environment, international students have to adapt to a new cultural and social environment simultaneously.Studies of international student adjustment discuss a range of problems, including the pressures created by new role and behavioral expectations, language difficulties, financial problems, social difficulties, homesickness, difficulties in dealing with university and other authorities, academic difficulties, and lack of assertiveness inside and outside the classroom.

As far as the author's experience when studying in Australia, some Muslim Indonesian students difficult to engage in a bit of food problem and rituals perform, Australian perception to Islam, homesickness and acculturation with host. 
Muslim Indonesian students in Australia also lack of language competence and selfconfidence further affects their capacity to do so. However, cross cultural adjustment is not solely determined by the international students themselves: it is shaped in relationships with others and affected by differences in values.

\section{Literature Review \\ Social Networking Sites}

Social networking sites are "webbased services that allow individuals to (1) construct a public or semi-public profile within a bounded system, (2)articulate a list of other users with whom they share a connection, and (3) view and traverse theirlist of connections and those made by others within the system" (Boyd and Ellision, 2007 in Veltri and Elgarah, 2009). Four popular types of social media and networking sites areFacebook, YouTube, Twitter, and smart mobile phone.

Facebook is a social networking site what has come to be known as 'lifestreaming', "a time-ordered stream of documents that functions as a [semipublic] diary of your electronic life". It is semi-public in the sense that it can be read by all one's contacts, called 'friends'. The postings can be in the form of comments, photos, music and video files, as well as links to other pages or external sites. Facebook also provides a private 'chat' which can be used to communicate with a single 'friend', and functions as an email. In the case of this study, Facebook was initially added as a way, suggested by the students taking part in the pilot study, of sharing photographs and keeping in touch, as Facebook was checked.

YouTube is a video-sharing website that began in 2005 that "allows individuals tointeract with the global community by viewing and sharing user generated video content". Because so many videos are shared by people around the world,traditional stereotypes of groups of people begin to decline. People have the opportunity tocomment on videos and participate in discussions and conferences. Numerous people have usedYouTube, and this innovation "became a driving force for change around the world" (Ostrow,2010). YouTube has over 78 million users with over 150,000 videos uploaded daily (Lake,2009). Many companies use videos to promote their business to other countries.

Twitter is a form of social media that allows people to communicate information through micro blogging. People use microblogging to "talk about their daily activities and to seek orshare information" (Java, et. al., 2007). Twitter is a social-networking site created in 2006 torelay real time information to users. Twitter has influenced intercultural dialogue because manypeople worldwide are focused on the individual lives of others and have the desire for connectionand knowledge of events. This example of social media has shortened the ties of distance intoknowing exactly what someone is doing without physically communication face-to-face withanother person.

Lastly, smart mobile phone combines the function of a mobile phone, MP3 player, and instant messenger. Smart mobile phone also combines new innovative features, such as the touch screen and wireless Internet access, and it encompasses different applications that include Facebook, YouTube, Twitter, Instagram, LinkedLink, Path, We Chat, Line, Cocoa Talk, MyPeople and other things. People can use to smart mobile phone connect with others on social media sites in a convenient, accessible manner; 
they can interact on the Internet without being face-to-face with others or even at a computer.

\section{Cultural Differences and Cross Cultural Adaptation}

There are differences in the way that people who identify with different cultures, based on both national identity and gender, manage their communicative behaviors within social network sites, (Rosen, et. al, 2010). These differences can be understood through Hofstede's dimensions.

Hofstede (1997:28 in Novera, 2004) identifies four main dimensions in which differences in values can be identified, describing these as: power distance, individualism versus collectivism, masculinity and femininity, and uncertainty avoidance. Power distanceis about how a culture deals with status inequality and authority; "the extent towhich the less powerful members of institutions and organizations within a country expect andaccept that power is distributed unequally". Masculinity and femininity describe thedistribution of roles between the genders; for example, assertive and competitive vs caring andnurturing.

Individualism versus collectivism refers to relationships between individual and others. Most Asian people live in the societies that value what is referred to as 'togetherness', and think of themselves as a 'we' group. They typically relate to extended not nuclear families and "areintegrated into strong, cohesive ingroups which continue throughout a lifetime to protect inexchange for unquestioning loyalty" (Jandt, 2001:200). In individualist Western culturespeople think more in terms of ' $I$ ' than 'we' and focus on the interests of themselves and their immediate family. In an individualist culture the cardinal values are creativity, bravery, self-reliance, and solitude.

Hofstede defined that uncertainty avoidance refers to "the extent to which the members of a culture feel threatened by uncertainty or unknown situations". People from strong uncertainty avoidance cultures are active, expressive of their feelings, aggressive, emotional, compulsive, security seeking, and intolerant; while those from weak uncertainty avoidance cultures, such as Southeast Asian cultures are contemplative, less aggressive, unemotional, relaxed, accepting personal risk, and relatively tolerant (Jandt, 2001). The latter cultures also tolerate ambiguity and value harmony.

Jandt asserts that students from high uncertainty avoidance cultures expect their teachers to know all the answers, whereas in low uncertainty avoidance cultures, students do not expect their teachers to know everything. In relation to social networking, differences in individualistic and collectivistic culturesare apparent in users' communication and behavioral styles.

With regard to social networking sites, differences in individualistic and collectivistic cultures are apparent in users' communication and behavioral styles. How people from individualistic cultures focus on meeting new people and being seen by many people, rather than maintaining their already existing relationships. On the other hand, people from collectivistic cultures utilize social network sites to "maintain close relationships with asmall number of ties instead of creating new connections with people" (Rosen, et. al, 2010).

Kim and Gudykunst (1988 in Wang, 2006:19) proposed the general term of cross-cultural adaptation which can be used to describe the adaptation 
process of both long-term immigrants and refugees and short-term sojourners. The researchers defined cross cultural adaptation as a dynamic socialization process by which individuals interact with a new and unfamiliar environment.

The goal of the process is to achieve an overall person-environment "fit" for maximization of one's social life chances. Communication is viewed as the core of cross-cultural adaptation, because an individual interacts with his/her environment through communication activities (Furnham \& Bochner, 1986). Cross cultural adaptation seems to be more neutral and representative than terms such as acculturation, assimilation, ethnicity, and cultural pluralism.

Kim (2001 in Wang, 2006:19) defined cross-cultural adaptation is "as the entirety of the phenomenon of individuals who, on relocation to an unfamiliar sociocultural environment, strive to establish and maintain a relatively stable, reciprocal, and functional relationship with the environment "Kim developed the integrative cross-cultural adaptation theory to conceptualize cross cultural adaptation and to explain how different factors influence individual adaptation. The conceptualization of intercultural transformation is integrative and theoretically sound. However, the concept remains difficult to operationalize in empirical testing situations partly because intercultural identity development, one of the three adaptive outcomes, is based on postmodern thinking.

Regarding to the social networking sites use: the Internet has become one of the most popular media used by immigrants, where they can electronically communicate with their family and friends in their native countries as well as with the local people in the host countries. In an online environment, the host social communication and the ethnic or religion social communication are important components that can facilitate or impede adaptation (Chen, 2009). Social networking sites have a social, physical, and cultural influence on cross cultural adaptation.

\section{Understanding Indonesia and Australian Education}

Indonesia is a multi ethnic country. There are more than five hundred ethnic groups speaking more than 300 distinct languages living in a country scattered over 13.000 islands each with its own identity. Indonesia is characterised by linguistic, cultural, religious and local diversity; but is also unified in certain respects, as indicated by the widespread use of Bahasa Indonesia and the national flag, and the dominance of Islam in religion. Indonesia's national motto is Bhinneka Tunggal Ika, an old Javanese phrase meaning 'They are many; they are one', usually translated as 'Unity in diversity' (Sneddon, 2003).

This includes cooperative harmony, decision by consensus (musyawarah mufakat) and mutual assistance (gotong royong) in accomplishing economic tasks. In terms of Hofstede's individualism or collectivism, Indonesian culture is definitely collectivist. Indonesians maintain traditionnal family values, group concerns are more important than individual concerns.

Studies on Indonesian ethnic groups have identified three core values of Indonesian cultures. First, Indonesian are characterized by a general emphasise of sociability, maintaining friendly relationships with others. Second, Indonesian culture is characterized by emphasis on the community than on the individual. Third, Indonesia puts an emphasis on 
maintaining a steady state life style that is smooth (Rusdi, 2000:16).

In Indonesia, the teacher is seen to be a moral authority and students are expected to defer to all their superiors, including teachers. Teachers are also viewed as the source of knowledge - while knowledge is viewed as a more or less fixed sets of facts to be transmitted and digested by thirsty learners, later to be regurgitated in test (a deficit model of learning). In the typical secondary school classroom teachers mostly dominate talk. Teachers urge the students to listen, to obey and to memorize things (Buchori, 2001).

Indonesian school students are not encouraged to ask questions of their teacher, and are reluctant to ask questions even when they are invited to do so. Questioning is seen "to challenge teacher's authority, and to demonstrate one's arrogance or ignorance - to risk the possibility of punishment or personal humiliation (loss of social face)" (Lewis, 1997:13 in Rusdi: 2000: 16). This can have negative long-term implications, given the need to formulate questions and develop critical thinking in tertiary education.

When students are in a foreign language context, language becomes a key factor in adjustment. In Indonesia, English is learnt as a foreign language and though it is one of the compulsory subjects in secondary and tertiary education, it is taught for only three hours per week in Lower Secondary School and four hours a week in the Upper Secondary School. Moreover, "English is seldom used in the classroom as teachers tend to use Bahasa Indonesia to carry out their English lessons in the classroom-except, perhaps, when greeting students before the sessions get started and then when students are dismissed" (Mustafa, 2001:306).
Australia is a major global provider of international education, and is the third largest provider at degree level after the United States and the United Kingdom. In 2013, there were 231.186 international students enrolled in Australian higher education, including more than 150,000 on shore in Australia. This was 0,4 per cent more international students than in 2012 and constituted 22 per cent of all students enrolled in Australia (Australia Education International, 2013).

The top five nationalities contributed of Australian's higher education enrolments were mainland China, India, Republic of Korea, Vietnam and Thailand. In between 2011 - 2013, around 17.000 students from Indonesia were enrolled in Australian schools and higher education institutions. The majority of whom (70.0\%) were in either Business Studies, Information Technology, Social sciences, Hospitality and Engineering (IECB, 2013;DEEWR, 2013).

\section{Understanding Islam}

The Arabic word Islam means submission and it illuminates the essence of the religion itself (Egendorf, 2006). For the Muslim, prayer is not simply a mental or spiritual attitude or even just a matter of thanksgiving of the mind and heart. It involves a total bodily response, both sitting [on the floor, as mosques generally do not have chairs or pews] and putting oneself through a series of physical prostrations (Smith, 2010:1). Observant Muslims perform the prostrations (in which the individual kneels on the ground and places his/her forehead on the ground) and prayers five times each day. The word Muslim in Arabic means one who submits to the will of Allah (Ali \& Bagheri, 2009:48) and the prostrations 
that Muslims perform symbolize their obedience to Allah.

Like Christianity and Judaism, Islam is an Abrahamic, monotheistic religion (Ali, et. al, 2004; Egendorf, 2006); although Muslims use the word Allah to refer to the God of all humanity (Ali \& Bagheri, 2009:48). From early in life Muslim children learn that their religion is based on five explicit beliefs which are manifested in the five responsibilities that are often referred to as the five pillars of Islam. The five pillars are based on both the teachings of the Quran and the experiences of the prophet Mohammed. All faithful Muslims are expected to perform them (Smith, 2010).

The practice of Islam is based not only on the Quran, but also on the collected individual narratives of what Mohammed said and did during his lifetime- the hadith (Smith, 2010). The hadith and the Quran together became the basis for the code of law, or sharia, which governs the day-to-day lives of all observant Muslims (Blanchard, 2009). The Quran explicitly prohibits the consumption or practice of anything that is haram-deemed harmful or impure (Ali \& Bagheri, 2009).

In addition, the Quran stipulates that anything that could lead to harmful actions should also be avoided; hence women should dress modestly and should avoid private meetings with men, in order to negate the possibility of fornication or adultery (Haddad, et. al, 2006).

Another Islamic principle is that food should be prepared in a beneficial way: the term for anything beneficial is halal. Observant Muslims eat only halal foods much in the same way that observant Jews eat only kosher food. One of the main features of halal food is the avoidance of eating pork. Another of the halal food rules is the Islamic process of slaughtering meat.

\section{Muslim Indonesian, Muslim Students and General Issues}

Islam is not only the predominant religion in Indonesia but part of the framework of Indonesian moral values. Its day-to-day customs and requirements directly affect most Indonesian students in Australia. Muslims are required to pray five times a day: at dawn, at noon, afternoon, sunset and at night. Islam prohibits alcoholic beverages and eating pork; and animals such as cows and chickens must be slaughtered in accordance with Islamic religious requirements before they can be consumed (Novera, 2004:479).

The author also calls attention to the fact that many modern generation Muslim Indonesian students are embracing Islam in a more public fashion than their parents: Muslim women who were born in Indonesia are also deciding to wear the hijab even though their own mothers do not, and as a result Muslim women are an ever more visible presence on Indonesian modern campuses. The number of Muslim students attending Muslim schools is steadily increasing, young Muslims are attending more conferences and lectures than their parents do, and they aredeveloping a stronger connection to their religious heritage in general.

This may be one of the reasons why westerners seem to be culturally insular. In other words, the influx of the 'other' coming to the Western host society to live freely, find employment and escape some undemocratic practices in their countries of origin, has been perceived by some Westerners as a threat to the stability and security of their own societies. Insularity, as a characteristic, is 
inevitably accompanied by cultural domination over others. What is good for themselves seems to some Westerners equally good for the whole world. In such societies, minority groups are often forced to accept the ideologies and standards of the economically and politically dominant groups.

In a study investigating Muslim students 'experiences on campus, Speck (1997:40) found that cultural differences and intolerance based on religious practice cast a dark cloud on the Muslim students educational experience. In his analysis of the transcribed interviews with Muslim students, Speck found that Muslim students identified four problems, among other things are Professors may use media that introduce misunderstandings about Islam and Professors may not make an effort to accommodate students'religious practices.

Mays (2003:160) found that Muslim students on the Brandeis University, United States of America, often feel frustration at both the media's portrayal of Islam and of the general lack of knowledge about Islam on the part of mainstream America. Although the hypothesis of the study on Muslim students at the predominantly Jewish campus was that the Muslim students would exhibit some symptoms of culture shock, this was not exactly the case.

Mays discovered that context specific/situational culture shock was evident in the experience of the participants in the studyand rather than reacting to American culture (read: western culture) in general, the participants found themselves reacting to specific, yet unexpected social encounters. The research showed this to be particularly true for female participants who felt uncomfortable because they were surrounded by other Muslim women who were wearing head scarves while they themselves wore no head covering (Mays, 2003:159).

\section{Methodology}

This research used qualitative methodological tools of interviews, participant observation and document analysis. The research questions became more focused as the analysis of the data proceeded. They changed and evolved as time went on. The topics explored could best be understood by probing these individuals' perceptions of their experiences.

For example, the interaction between students of different cultural backgrounds from their teachers, the thoughts and values of students and other nuances of behavior could only be elicited and understood by the qualitative interviewing technique used in this study. Students were encouraged to make comments related to their personal experiences, thus allowing the possibility of cross-cultural issues, which are part of the milieu, to emerge as a natural outcome of the choice of framework.

The 10 informants return to Indonesia from Australia in the study were aged between 20 and 40 years old, from a diversity of locations in Indonesia, from a mixture of academic fields, and enrolled at a number of universities in Australia. There were 5 men and 5 women Muslim students.

All informants were universities students (some of them has already graduated) because it was expected that their relative maturity and experience would enable more thoughtful reflections. Similarly, all were required to have lived and studied in Australia for at least one year. All informants were self selected (volunteers), has already came back to Indonesia, and were contacted through 
mailing lists from Indonesian Muslim communities in Australia and the Indonesian-Muslim Association in Australia to make an appointment to meet them.

All of informants would be interviewed when they were in Indonesia, whether they are finishing their study, doing a research, or just being in holiday in Indonesia between June - September 2013. The interview sought information from the informants concerning any difficulties they had experienced in relation to their course of study, social networking use, and social and cultural life in Australia, and asked them to identify positive aspects of Australian education and socio-cultural life.

\section{Selection and Profile of informants}

International students from an Muslim Indonesian background enrolled in some Australian Universities and who just return to Indonesia, were chosen as the target group for this study as indicated earlier. The interviews were mainly conducted using Indonesian.

Aminah (Interviewee A) is from Bandung, Indonesia in the 25 to 30 year old age group. She speaks fluent English, and has been in Australia for three years. Aminah completed high school in Bandung and studied marketing in Melbourne, Australia. At the time of the interview, she was just finishing studying for a Master of Business in Tourism Management in Queensland University. The interview was conducted from 1:45pm to 2:30 pm on August 8, 2013 in Bandung. Aminah is a practicing Muslim. She states that she goes regularly to the mosque at her school, and that she wears Islamic dress (hijab). Before she came to Australia, she has visited many European countries with her family.
Badrun (Interviewee B) is also from Bandung, in the 21 to 25 age group. He speaks Sundanese and Indonesian in addition to English moderately, and has been in Australia for one year. Having completed his high school education in Bandung, he was studying for a Master of Education in Curtin University. The interview with Badrun took place from 2:00 pm to 2: 45pm on August 9, 2013.

Komar (Interviewee C) is from Bogor, Indonesia, and aged between 21 to 25 years old. He speaks fluent Sundanese, a little Javanese and very fluent English and Indonesian. He has been in Australia for three years, completed an Bachelor of Business Management at Monash University. The interview with him was from 2:45 pm to 3:50pm on August 14, 2013.

Dinah (Interviewee D) is from Depok, Indonesia in the 25 to 30 year old age group, and speaks Indonesian, Sundanese, Malays, Javanese and very fluent English. She has been in Australia for three years. Although she does not wear Islamic dress or go to the Mosque regularly, she considers herself a good Muslim. She was studying for a Doctor of Biology and was in her final year of study in Queensland University. The interview with her was conducted from 5:0opm to 6:oopm on August 28, 2013.

Edi (Interviewee E) is from Lombok, Indonesia in the 25 to 30 year old age group. He speaks Indonesian in addition to fluent English, and has been in Australia for two years. At the time of the interview, he was just completing the Master of Information System in Curtin University. He is currently living Cimahi, Indonesia. He showed a great interest in participating in the study. The interview with him was from 3:20pm to 4:oopm on August 31, 2013. 
Fauzi (Interviewee F) is from Jogya, Indonesia in the 21 to 25 years old age group. He speaks Indonesian, Arabic and fluent English. He was just finishing studying for a Master of Antrophology, one university in Victoria, Australia. He said that he is religious and he has nonMuslim friends, both Indonesian and Australian. He has many books on Islam and Christianity either in his house in Indonesia or in his apartment in Australia, there are sorne Quranic verses on tables and walls. The interview with him took place from 12:00 noon to 1:00pm on September 5, 2013 in Jakarta.

Gharib (Interviewee G) is from Jakarta, aged between 30 to 35 . He speaks Indonesian and fluent English, and has been in Australia for four years. Gordon has completed a university doctoral in Queensland University, and studied accounting. I have known Gharib socially for more than 2 years. This helped us to get quickly past the stage of mere superficial social interaction during the interviews. Gharib was shy but eager to discuss his experiences in school and society.The interview with him was conducted from 12:00 noon to 1:0opm on September 6, 2013 in Jakarta.

Halimah (Interviewee $\mathrm{H}$ ) is from Tasikmalaya, in the 25 to 30 year old age group. She speaks Indonesian, Sundanese and fluent English, and has been in Australia for four years. She was completing a Master in Political Science in Australian National University. The interview with Halimah was from 9:20am to 9:45am on September 7, 2013 in Jakarta.

Iradah (Interviewee I) is from Solo, in the 25 to 30 age group. She speaks Javanese, Arabic and very fluent English. She has been in Australia for three and a half years. She was completing her study for a Bachelor of Communication Studies in La Trobe University. The interview with her was from 2:0opm to $2: 45 \mathrm{pm}$ on September 8, 2013 in Jakarta. She is articulate and outspoken. She expresses anger toward the patriarchal structures and systems of thought which dominate the Indonesian culture with which she is familiar. She insists that Islam does not discriminate against women but Indonesian culture does.

Jamilah (Interviewee $\mathrm{J}$ ) is from Medan, Indonesia aged between 21 to 25 years. She speaks Indonesian, Malay and fluent English. Jamilah has been in Australia for four years; she completed Doctor in Architecture, Melbourne University. She said that she loves to wear hijab and has never experienced any pressure from her non muslim friends to wear it.The interview with her was conducted from 2:0opm to $2: 45 \mathrm{pm}$ on September 11, 2013

\section{Results}

With regard to each of the questions asked about social networking and cross cultural adaptation, the author found similar themes among the answers of the informants. The results are supported by some direct quotations from the interviewees' responses.

First question: All of the participants that were involved in the study used social networking. They average used Facebook, Twitter, Skype, YouTube, LinkedIn, and Google+. Most of the participants use the social networking sites multiple times a day, and some log in weekly to communicate with friends and family. A few sites are checked a couple times a month just to get updates and check the news.

The amount of time the interviewees spent on social networking sites varies from about 5 minutes when checking updates to a few hours if they are 
talking to friends. Only three of the informants use of smart mobile phone.

"I use Facebook to communicate with friends all around the world. A lot of Muslim Indonesian students who study in Australia also use this one, and I probably use Facebook than any other social media or networking because a lot of my friends, especially my muslim friends, also use Facebook to interact even though mostly of them also have twitter" (Interviewee C).

"I have accounts on almost all the popular sites Facebook, Twitter, YouTube, and of course Gmail. I log in multiple times a day, totaling about two hours" (Interviewee D).

Second question: The informants of this study used social networking sites to communicate with their friends and family and to stay in touch with people whom they cannot talk to face-to-face. Staying connected to people that they do not talk to or see often is important for the relationships in order to maintain contact and connection. Additionally, social networking sites are used to share information and to discuss information about Islam and the way of Muslim adjusting in non Muslim environment. The degree of how involved people are with social media sites varied; some informants were more passive with interacting online, while others were very active users who communicated frequently.

"When I use Electronic mail and Facebook, I share a lot of articles including the potrayal of Muslim people in Australia. Most students are very critical about the government, and we share pictures and news links on what's happening Muslim and Islamic development in Australia. Personally, I also use Skype to talk to my family and my Muslim friend in Indonesia. At the first time, I asked what I should do when there is nothing halal meats here or I get difficulties to perform pray" (Interviewee A).

"As far as interactions go on Facebook, I don't interact much; I only observe. For example, on Twitter I follow a couple of links that I'm interested in. So similarly on Facebook, there are many people who update and post interesting news and videos, and if I feel like replying or commenting I will, but mostly I just observe" (Interviewee B).

Third question: Before the Muslim Indonesian students arrived in Australia, they had only a few contacts, along with professors, and they communicated through email. In this respect, social media did not play a prominent role in developing relationships; however, social networking sites were still used to become more familiar with the culture through talking with their friends about the cultural experience. Mostly informants also scrutinize the way of Muslim people survive in non muslim environment, like Australia, before they arrive in Australia. They prepared anything information to live in Australia by means of contacting with the prior those Muslim Indonesian students who has arrived and lived before them.

"I only knew a few Muslim Indonesian students living in Melbourne at the time, and I used email totalk a bit. They actually helped me to adjust to the Australian culture, especially dealing with culture shock" (Interviewee $H$ ). 
"A few years ago I didn't use social media, so I communicated with my professors through email. I also did not forget to let her know that I am a Muslim so that I expect that she anticipated to face me" (Interviewee G).

Fourth question: The interviewees' social networking use helped them to be prepared in adjusting to Australian culture as well as they consider themselves a good Muslim. Social networking sites fostered connections and created awareness of different aspects of the culture, and some people used social networking for entertainment in order to understand these contexts.

"My interactions with others were limited and social networking increased my awareness.For example, when I was in Indonesia before came to Australia, I just little bit know what Easter day was. In my opinion, it was a Western thingand I didn't really care or understand until I talked to people about it. And Christmas...it's a festival, we all celebrate it, but when I came here, I saw how a lot of people go shopping on Boxing day after day of Christmas. The only way I understood was watching videos and using Youtube to learn about the importance of the holidays and appreciate what other people do as well as I learn how the Muslim people perform their worship and celebrate Idul Fitri or Idul Adha (two biggest Islamic celebreting day per year) in Australia" (Interviewee D).

"I used Facebook and YouTube more so I could get to know more people so that I could be more prepared for life in the Australia. With the help of Facebook and YouTube, I learned what was going on Muslim students shopping a heejab fashion, Islamic books and prayer mat, eating out halal restourants, watching nasheed (Islamic singing), and searching Masjid or Musholla (Communal Islamic Praying Place) in Australia" (Interviewee H).

Fifth question: From the responses of the interviewees on whether social networking sites helped them to overcome stereotypes or biases towards Australian culture, there were mixed answers. Some informants felt that social media both strengthens and weakens stereotypes because some sites advocate overcoming stereotypes, while others are geared towards ostracizing groups and promoting the stereotypes.

For example, some videos on YouTube directly make fun of cultures, which consequently spreads the biases. On the other hand, some videos acknowledge cultural differences and demonstrate the purpose of informing an audience that is unfamiliar with certain norms, traditions, practices, and beliefs.

Some of the interviewees expressed caution while viewing videos or participating in discussion groups focused on stereotypes. They were aware that different viewpoints exist and that it is important to be critical and skeptical of the sources so one can create a wider worldview perspective. Lastly, one student that was interviewed expressed how she did not have preconceived stereotypes of the Australian culture, and so social media had no effect on overcoming stereotypes or biases.

"I don't think that YouTube maintain or emphasize stereotypes because people trust what they want to trust" (Interviewee C). 
"I generally watch videos and see if things are contradictory. I look at multiple views. However much we try not to stereotype, we still have perceptions of certain groups; it's a psychological perception that we cannot change so we must be cautious" (Interviewee B).

"This question assumes that we all have stereotypes and biases of Australians before we came here, which I really didn't have" (Interviewee I).

"In my opinion, social media reinforces the stereotypes, especially of the ignorance of Australians, but that's just the stereotype; not every person thinks that way" (Interviewee J).

Sixth question: When asked if social networking use use helped the interviewees make Australian and nonAustralian friends, the responses that it was received were inconsistent. The author has come to the conclusion that the source of the discrepancy was from the wording of the question; social networking sites does not necessarily help people make friends. It was found that from the Muslim Indonesian students that were interviewed, social networking helps to strengthen, build, and maintain friendships and already existing relationships.

"Not really. I think I use social networking sites more to keep in touch with people in Indonesia and my friends who studying in other cities or different state in Australia than I use it to connect to people here in Victoria, Australia. It's probably because of my situation, I join some Muslim students communities, whether Muslim Indonesian communities or non Indonesian communities. Every week I always get invitation either by phone or by email to attend $B B Q$ party from one of Muslim community. I use Facebook just uploading my photo or video our event like $B B Q$ party or Islamic teaching in our Islamic community gathering or meeting" (Interviewee F).

Seventh question: Muslim Indonesian students faced adjustment challenges, like culture shock, when they arrived in Australia, and social networking sites helped to overcome the challenges. The interviewees used these media to become more integrated into the new culture with mailing lists and social groups online. Social networking sites were used to understand cultural differences and the local, everyday life, especially seen through photos and video of social cultural events. Lastly, social networking was used to help the Muslim Indonesian students practicing the worship and Islam regulation in the middle of non Muslim society like in Australia.

"It was a new environment that took time to get used to. I had some mailing list that included so many of the Muslim Indonesian students studying at the university, specially in Queensland, so basic communication occurred online with this group. A few Muslim Australian and Muslim non Australian were on the list as well, and they organized parties and religious events for the Muslim Indonesian students. It was a social medium group that was smaller than Facebook" (Interviewee A).

"I experienced culture shock. When I first came here, I went to gatherings and parties, which sometimes were at the nightclub. I felt uncomfortable because I didn't 
go to the nightclub in Indonesia and I did not drink alcohol due to my religion, but it's different here because it's more common for students to go to the nightclub. It's not wrong and it's not right; it's just different. I understand it now because I looked at a lot of pictures on Facebook and other social networking sites and I think, 'Ok, most people do that; it's common here even though I will not drink and just meet my Australian friends" (Interviewee C).

Eight question: The analysis from the interviewees' responses reveals that they feel satisfied after using social networking sites. These media keeps people in touch with each other, and it is very convenient for communication purposes, especially discussing Islamic matters such as solving with diet problems, communicating with non Muslim and interacting with different sex. Most of the informants felt that it was satisfying to stay updated with their friends' and families' lives, even though they may be in different countries.

However, one point was brought up that sometimes people spend too much time on social networking sites to where it can become addictive because people have the desire to constantly be aware of what people are doing; so, it is important to balance how much time one spends on social media sites.

"It's good to see what people are doing, but other times I feel like I waste so much time. You need to balance how much time you spend on social networking sites. You can't rely solely on social networking when building relationships" (Interviewee F).

"Social network is a comfortable way to communicate with people when you can't call them on the phone or see them face-to-face" (Interviewee D).

Social networking sites are convenient to communicate with people around the world. The sites start learning through the exchange of messages and the sharing of links and information about the way of Muslims living in Australia. They are online sources where people can stay socially connected to their friends, family, peers, and acquaintances in Indonesia.

However, there are many disadvantages of using social networking sites which was experienced by informants. First, privacy becomes an issue because people post and share personal information on the Internet, and anybody can view the sites. Considering the information that can be shared publicly and the information that should stay private is important. In addition, social networking sites can become time consuming and addictive when people develop the habit of always talking to people on the Internet for long periods of time.

Lastly, social networking sites present a barrier to communication because people are unable to see how others react to their messages and hear their tones of voice because they are not speaking face-to face, and messages may be impersonal when sending them online.

"I can share and post interesting news and be updated with what is happening Islamic cultural live in Australia. The disadvantages come with the privacy issue. I think people should think before posting things. Particularly, from my personal view, I'm not comfortable with sharing my personal things with anyone except my close friends, not on social media sites" (Interviewee J). 
"You can learn a lot of things through YouTube. You are not face-to-face with people. However, there's a barrier between interactions. When you chat online, it is efficient, but you can't see each other's facial expressions or gestures. For example, I cannot express my feeling to my friends in Indonesia when I saw one guy attacked my friend on the street" (Interviewee D).

Tenth question: Social networking contributes to one's sense of community both in the host and home countries of the international students. The informants of the study belong to social groups in Australia and in their home countries, maintaining contact with friends and family in Indonesia. One way that the informants maintained a sense of community through social media in Australia is through groups on social network sites that reflect their interests.

In order to maintain a sense of community and belonging with their home countries, the interviewees maintain contact with the people they knew from their home countries and followed news articles to stay informed with current events. Overall, specific communication tools contribute to feeling a sense of community in different countries. For example, Muslim Indonesian students use Twitter and Facebook to maintain a sense of community back in Indonesia, while simultaneously, they mostly use mobile phone and mailing lists to maintain bonds and connections with people in Australia.

"I use Twitter and Facebook because it originated from the campus network and I can talk to my friends in Indonesia. I share videos, articles, and pictures with my friends so that we can still keep up with what's going on in each other's lives. In Australia, I also actually use Facebook, which makes me feel like I'm part of a Muslim family. However, most likely to see each other by face to face, I prefer use mobile phone to communicate with them" (Interviewee C).

"I use social networking media to maintain contact with people here and in Indonesia. After coming to Australia, I started using these media so I never lost contact with my old friends or family in Indonesia. I know what's going on in Australia because I follow the news on television and talk to people mostly by phone rather than on social media sites" (Interviewee I).

Many interesting points were brought up that should be noted in the study. First, social networking sites have become an integral part of our lives that the distance among cultures has been decreasing. Because of this process, social networking sites have positively impacted cross cultural adaptation.

"Social networking sites helped me a lot to get adjusted to Australian life to overcome the cultural gap especially between Islam and non Islam culture. Thanks to social network like Facebook and YouTube, I got a lot of information that Islamic values also was applied by australian people although they are not Muslim such as respect to the other, keeping clean environtment, and also hard worker. Previously I prejudice most Australian people love drink alcohol, living together without married, and anti Asia and Islam.In short, Social networking sites helped to make my transition easier" (Interviewee C). 
"There is a huge difference in the way social networking sites are used across cultures due to the different ways people are brought up. I feel that the boundaries are thinning across cultures over the generations. This thinning of boundaries causes cultures to be more similar because of Westernization and modernization, so in this way, social networks and cross cultural adaptation have grown. If you look at the diffusion of social networks across cultures where there is Internet, it has been pervasive. So over time, I don't think that social networks and cultures will be homogeneous; there will be heterogeneity. The way cultures use social networking sites to adapt to lifestyles in other countries are different" (Interviewee A).

Lastly, social networking sites helped Muslim Indonesian students learn the language and ease the adjustment in adapting to the university life in Australia. The interviewees felt that social networking sites was a great way to stay connected to in both Australia and their home countries. Social networking sites strengthen the links among people across the world, creating an environment for learning and understanding.

"Social networking sites are good to link people across countries so that they can understand each other. For people who are travelling to another country, social networking sites are a good place to learn about the host culture, and I would recommend using these media, from my personal experience in adjusting to life in Australia" (Interviewee $G)$.

\section{Finding Analysis and Discussion}

From the informants' reports, one can infer that people strengthen, build, and maintain relationships through social networking sites. The interactions and conversations establish interconnectedness, which is an important component for communicating with people in the host and home countries.

Before arriving in Australia, the informants spoke about using some social networking sites to become more familiar with the Australian way of life and to understand cultural norms and traditions, especially the culture which is contradicted with Islamic rules. Social networking sites serve as a place for interaction and conversation in order to get in touch with contacts abroad in Australia and ask about the cross cultural experience.

Furthermore, social networking sites helped the informants to overcome stereotypes toward Islam or just reinforce them, the interviewees acknowledged the stereotypes and biases and could shape their perceptions around the multiple sources. The information on the different points of view was available to them, and simply being aware and recognizing the different impressions create a wider world view perspective on cultures.

Simultaneously, keeping in touch with friends and family back in one's home country is just as essential. Social networking sites provides an outlet where people have the opportunity to communicate with friends and family in order to stay updated, aware, and informed of current events. Informans spoke about how social networking sites helps them feel like they are still part of their home country even though they may be across the globe in their host country. Social networking sites exemplify resources for how people can foster a 
sense of community and feel like they belong to multiple cultures.

Social networking sites such as Facebook and Twitter became a medium for expressing their difficulties' experience as well as asking some advices from his or her Muslim friends that how to deal with these problems. For example, five informants told that they survive in the middle of "alcohol culture" and share their story with their distant friends through Twitter and Facebook. The most fundamental problem of a social-cultural nature was that day-to-day Muslim practices were not always understood or appreciated in Australia. Seven informants specifically mentioned difficulties in this area and they shared these problems via social networking. Some difficulties that those students met such as; finding a place for praying, and washing prior to praying.

As the Muslim students in this study spend most of their time outside their houses, much of it on campus, finding a place to pray is one of their principal daily concerns. Informants also complained it was difficult to find halal food: Muslim Indonesia students experience different adjustment problems to those facing non-Muslim students. They sometimes used Facebook and YouTube as media to obtain information about how to cope with this problem.

Most informans would rather "face to face" than using social media or social networking sites for discussing or publicizing Islamic teaching (Da'wah) such as; socializing Islamic values, interpreting $\mathrm{Al}$ Qur'an an $\mathrm{Al}$ Hadits or learning Arabic language or how to read $\mathrm{Al}$ Qur'an appropriately (Tajwid). They share more their personal experience when they use social media/networking sites such as finding halal food or making non Muslim friends.
Nevertheless, most informans showed the positive aspects of Australian culture through social media. They valued Australia's clean environment, and friendly punctual people. As many saw it, Australia is a multicultural society, containing many differences, and people are taught how to respect differences. Australian people did not interfere with each other's business; and they also respected disabled people and the elderly, who were given priority and easy access. Some informants emphasized that they saw Australians as very open and tolerant of differences.

\section{Conclusion}

In conclusion, this research shows that three aspects of social networking sites use on cross cultural adaptation: most informans use them tend to maintain relationships, to make cultural adjustment and to share cultural experiences.

The results of this research emphasize the importance of how seeking connections on social networking sites impact intercultural adaptation. Most informan said that people strengthen, build, and maintain relationships through social networking sites. The interactions and conversations establish interconnectedness, which is an important component for communicating with people in the host and home countries.

After arriving in the host country, the informan met people in Australia, and they used social networking sites to connect to the individuals. Forming these relationships created a sense of belonging and integration into the new culture, and social networking sites contributed to this development. Simultaneously, keeping in touch with friends and family back in one's home country is just as essential. Social networking sites provides an outlet 
where people have the opportunity to communicate with friends and family in order to stay updated, aware, and informed of current events.

The informan spoke about how social networking sites helps them feel like they are still part of their home country even though they may be across the globe in their host country. The result of this research indicated that the recurring themes of connections, interactions, and relationships were illustrated and influenced how the informan overcame adjustment challenges and established a sense of community and feeling of belonging in both the host and home countries.

Adjustment is an essential factor in cross cultural adaptation, and social networking sites influences this process. Before arriving in Australia., the informan spoke about using some social networking like YouTube and Facebookto become more familiar with Australian way of life and to understand cultural norms and traditions. Social networking sites serve as a place for interaction and conversation in order to get in touch with contacts others Muslim Indonesian students in Australia and ask about the cross cultural experience.

Furthermore, becoming aware of stereotypes is part of the adjustment process. Whether social media helped the informan to overcome stereotypes or just reinforce them, the informan acknowledged the stereotypes and biases and could shape their perceptions around the multiple sources. The information on the different points of view was available to them, and simply being aware and recognizing the different impressions create a wider world view perspective on culture

Social networking sites are mostly used to share information, news articles, photos, resources, and to discuss information about Islam and the way of Muslim adjusting in non Muslim environment. They also used social network sites for helping them from culture shock then they share this experience to their friends. Generally they satisfied in using social networking sites because these media are able to keep people in touch with each other, especially discussing Islam and accelerating to get solution to some problems with regard to deal with stereotype and prejudice. Social networking sites exemplify resources for how people can foster a sense of community and feel like they belong to multiple cultures.

\section{Limitations and Further Research}

However, there are several aspects in which this study was limited. However, these limitations suggest a direction for future research. First, due to time constraints, I only interviewed 10 Muslim Indonesian students at some Australian universities when retur ning to Indonesia. Interviewing a larger number of students or expanding to more universities in Australia would be beneficial in creating a greater understanding of my research. In addition, the majority of the interviewees were from Asian countries.

For further research, Muslim Indonesian students from a wider range of western countries around the world could be interviewed in order to gain a broader perspective of social media and cross cultural adaptation from a more diverse population. In addition, the age range of the participants could be expanded to include more people, and not merely those adjusting to university life.

Older and younger generations could be studied, in addition to the working class and people moving to Australia for reasons other than 
education, such as business and travelling. Lastly, Muslim Indonesian could also be interviewed in order to learn about how their social media use impacts cross cultural adaptation in other countries, which then can be compared and contrasted with people coming to the Australia.

\section{References}

Abu-Absi, S., 1996, Stereotypical Images of Arab Women.Phi Beta Delta :International review 37,(6),pp.6o65.

Ali, S. R., \& Bagheri, E. 2009, Practical suggestions to accommodate the needs of Muslim students on campus, New Directions for Student Services, 125, 47-54.

Ali, S. R., Liu, W., \& Humedian, M. 2004, Islam 101: Understanding the religion and therapy implications. Professional Psychology: Research and Practice, 35, 635-642.

Australian Education International, 2013, End of Year Summary of International Student, Enrolment Data, Australia Government 2013

Buchori, M., 2001. Notes on Education in Indonesia. Jakarta: Jakarta Post and Asia Foundation.

Blanchard, C. M., 2009. Islam: Sunnis and Shiites. Congressional Research Service., Retrieved from www.crs.gov March 12, 2013

Chen, G. M., \& Zhang, K., 2010. New media and cultural identity in the global society. In R. Taiwo (Ed.), Handbook of Research on Discourse Behavior and Digital Communication: Language Structures and Social Interaction (pp. 801-815). Hershey, PA: Idea Group Inc.

Chen, W., 2009. Internet use and intercultural adaptation: A case study on Chinese immigrants in Singapore. Paper presented at the annual meeting of the International
Communication Association, New York City, NY.

Department of Education, Employment, Workplace Relations, DEEWR (2013). Commonwealth of Australia, Higher education statistics collection. [Online] http://www.deewr.gov.au/highered/ statinfo.htm, retrieved March 12, 2014

Egendorf, L. K.,2006. Islam in America, Farmington Hills, MI: Greenhaven.

Furnham, A. and Bochner, S. 1986, Culture Shock: psychological reactions to unfamiliar environments, Methuen \& Co. London

Haddad, Y. Y., Smith, J. I., \& Moore, K. M., 2006. Muslim Women in America: The Challenge of Islamic Identity Today. New York, NY: Oxford University Press.

Indonesia Education Country Briefing (IECB), 2013, http:// www.austrade.gov.au, Austrade, retrieved March 23, 2014

Jandt, F.E. 2001. Intercultural Communication. An introduction. London: Sage Publications.

Java, A., Song, X., Finin, T., \& Tseng, B., 2007. Why We Twitter: Understanding microblogging usage and communities. Retrieved March 5, 2014 from source: http://ebiquity.umbc.edu/paper/ht $\mathrm{ml} / \mathrm{id} / 367 /$ Why-We-Twitter-

Understanding- MicrobloggingUsage-and-Communities . 
Lake, L., 2009. YouTube: Social media marketing via video . Retrieved 27 February 2014 from source: http://marketing.about.com/b/200 9/02/22/youtube-social-mediamarketing-via- video.htm .

Mays, N. G., 2003. Muslim students at an American university: A postmodern ethnography in the new millennium. (Doctoral dissertation). University of Connecticut, Mansfield, CT.

Mustafa, B., 2001. Communicative language teaching in Indonesia: Issues of Theoretical assumptions and challenges in classroom practice. Journal of Southeast Asian Education, 2 (2), 296-308.

Novera, Isvet Amri, 2004, Indonesian Postgraduate Students studying in Australia: An Examination of their Academic, Social and Cultural Experiences, School of Social and Behavioural Science, Swinburne University of Technology,International Education Journal Vol 5, No 4, 2004 , http://iej.cjb.net, page: 475

Ostrow, A. 2010. YouTube is the top social media innovation of the decade, Retrieved March 4, 2014 from source:

http://mashable.com/2009/12/22/y outube-2010/

Rusdi, 2000. Informational Sequence Rhetoric in Language Learning in Classroom: A Comparative Study between Indonesia and Australian Students, Dissertation, Department Language and Learning, Curtin University of Technology, Australia.
Rosen, D., Stefanone, M. A., \& Lackaff, D., 2010. Online and offline social networks: Investigating culturallyspecific behavior and satisfaction. In Proceedings of the 43rd Hawai i International Conference on System Sciences. New Brunswick: Institute of Electrical and Electronics Engineers, Inc. (IEEE).

Sawyer, Rebecca., 2011. The Impact of New Social Media on Intercultural Adaptation, Senior Honors Project, University of Rhode Island.

Smith, J. I., 2007. Muslims, Christians, and The Challenge of Interfaith Dialogue. Oxford: Oxford University Press.

Smith, J. I., 2010. Islam in America. New York, NY: Columbia University Press.

Speck, B. W., 1997. Respect for Religious Differences: The Case of Muslim Students. New Directions for Teaching and Learning.

Sneddon, J., 2003. The Indonesian Language: Its history and role in modern society. Sydney: UNSW Press.

Wang, Yin, 2006. Internet Use and it's Implication for Cross Cultural Adaptation among Chinese Students In USA, Doctoral Dissertation, Kent State University, Ohio, USA.

Veltri, N.F., \& Elgarah, W. 2009, The Role Of National Cultural Differences In User Adoption Of Social Networking. Paper presented at the Southern Association for Information Systems Conference, Charleston, SC. 